\title{
What is the best fertilizer for Marandu and Xaraes palisadegrass production in the short term?
}

\author{
¿Cuál es el mejor fertilizante para una pradera de Marandu y \\ Xaraes en el corto plazo? \\ Adauton Vilela de Rezende ${ }^{1}$, Flávio Henrique Silveira Rabêlo2*, Rafael Tadeu dos Santos ${ }^{1}$, \\ Hugo Abelardo González-Villalba ${ }^{3}$, Carlos Henrique Silveira Rabelo ${ }^{4}$, Marcos Rodrigues ${ }^{3}$
}

\begin{abstract}
Several fertilizers with different efficiency and price are commercially available to increase the yield of pastures, generating doubts about which should be chosen for fertilization, especially regarding short term operation returns. Our objective was to investigate the effect of simple and compound fertilizers on the production, chemical composition and economic parameters of Marandu and Xaraes palisade grass in the short term. The fertilizers Urea, Super N, 08-28-16, 30-00-20 and 20-10-10 were evaluated in three cuts of the pasture. The overall rate of tiller occurrence, dry matter production, crude protein content, total digestible nutrients and digestible energy of Marandu palisade grass increased with the supply of nitrogenous fertilizers, while neutral detergent fiber (NDF), acid detergent fiber and hemicellulose content decreased. Fertilization using Super N resulted in higher production of mass per kilogram of fertilizer applied and per unit of real $(\mathrm{R} \$)$ invested per hectare. The number of tillers of Xaraes palisade grass increased and NDF content decreased with the application of 20-10-10. Fertilization of Marandu palisade grass with Super $\mathrm{N}$ is more efficient from the economic and productive point of view than fertilization with urea. Comparing the grasses, Xaraes is more demanding in phosphorus and potassium than Marandu.
\end{abstract}

Key words: chemical composition; morphological characteristics; production cost.

\section{RESUMEN}

Existen varios fertilizantes disponibles comercialmente para aumentar el rendimiento de los pastos, generando dudas sobre cuál debe ser escogido para la fertilización, especialmente con respecto a la eficiencia y los costos de operación a corto plazo. El objetivo de este trabajo fue investigar el efecto de los fertilizantes simples y compuestos sobre la producción, la composición química y los parámetros económicos en una empalizada de Marandu y Xaraes a corto plazo. Se evaluaron los fertilizantes úrea, Súper N, 08-28-16, 30-00-20 y 20-10-10 en tres cortes de la pradera. La tasa global de macolla, producción de materia seca, contenido de proteína cruda, nutrientes digestibles totales y energía digestible de empalizada Marandu aumentó con la aplicación de fertilizantes nitrogenados, mientras que la fibra detergente neutra (NDF), fibra detergente ácida y contenido de hemicelulosa disminuyeron. La fertilización con Super $N$ resultó en una mayor eficiencia por el aumento de producción por kilogramo de fertilizante aplicado y por unidad de reales $(R \$)$ invertidos por hectárea. En la pradera de Xaraes el número de tallos aumentó y disminuyó el contenido de NDF con la aplicación de 20-10-10. La fertilización en la empalizada de Marandu con Súper N fue más eficiente desde el punto de vista económico y productivo que la fertilización con úrea. Comparando ambas gramíneas, Xaraes fue más exigente en fósforo y potasio que Marandu.

Palabras clave: composición química; características morfológicas; costo de producción.

1 Departamento de Agronomia, Instituto de Ciências Agrárias, Universidade José do Rosário Vellano. Alfenas, Minas Gerais, Brasil.

2 Divisão de Produtividade Agroindustrial e Alimentos, Centro de Energia Nuclear na Agricultura, Universidade de São Paulo. Piracicaba, São Paulo, Brasil.

3 Departamento de Ciência do Solo, Escola Superior de Agricultura “Luiz de Queiroz", Universidade de São Paulo. Piracicaba, São Paulo, Brasil.

4 Departamento de Zootecnia, Faculdade de Ciências Agrárias e Veterinárias, Universidade Estadual Paulista "Júlio de Mesquita Filho". Jaboticabal, São Paulo, Brasil.

* Corresponding author: flaviohsr.agro@usp.br

Fecha de Recepción: 14 Junio, 2017.

Fecha de Aceptación: 19 Agosto, 2017. 


\section{Introduction}

Global food demand has increased every year, promoting a search for more efficient and economic production systems. Pastures when appropriately managed and fertilized represent economy in the ruminant production system of tropical regions (Barcellos et al., 2008). However, the high cost associated with the low use efficiency leads to a reduction of fertilizer utilization in areas occupied by pastures (Barcellos et al., 2008; Dupas et al., 2016a,b). In consequence, the lack of fertilizer utilization combined with low fertility levels in tropical regions determine the beginning of soil degradation processes, reducing the productivity efficiency of pastures (Dupas et al., 2016a,b; Rezende et al., 2015).

Nitrogen $(\mathrm{N})$ deficiency is the main limiting factor for dry mass production (DMP), since it is a structural component of chlorophyll and responsible for nitrate reductase activation (Dupas et al., 2016b). Thus the use of fertilizers can contribute to increase pasture production (Rezende et al., 2015). An adequate proportion between $\mathrm{N}$ and potassium $(\mathrm{K})$ is important for plant growth, since $\mathrm{K}$ is the second nutrient most extracted by forage and participates in enzymatic processes and protein synthesis in plants (Rabêlo et al., 2013; Rezende et al., 2015). Additionally, low phosphorus (P) availability in the soil decreases root development and plant tiller number, demonstrating the importance of this nutrient in pasture plantations (Rezende $\mathrm{et}$ al., 2011). Deficiencies of these nutrients can also affect the chemical composition of plants (Dupas et al., 2016a; Rabêlo et al., 2013; Rezende et al., 2015).

Previous studies showed greater tiller number production of Tanzania guineagrass with the supply of NP and NPK in relation to NK and KP (Oliveira et al., 2007), while DMP and crude protein (CP) content of Palisade grass increased with $\mathrm{N}$ fertilizer (Dupas et al., 2016a). Combinations of $\mathrm{N}$ and $\mathrm{K}$ rates did not modify DMP, CP or the constituents of fiber fraction in Elephant grass (Fagundes et al., 2007). Supply of $P$ increased height, tiller number and DMP of Xaraes palisadegrass (Lopes et al., 2011) and CP content in natural pasture (Gatiboni et al., 2008). These effects show the importance of fertilizer utilization in pastures, but the understanding of how the combination of nutrients can affect production and nutritive value of grasses needs to be better investigated (Dupas et al., 2016a).
Furthermore, the DMP and chemical composition of forages varies with soil type, amount and type of fertilizer, genetic differences between cultivars and interval between cuts (Dupas et al., 2016a; Rezende et al., 2015). Therefore, the knowledge generated through research, especially that resulting in new technology, can be adopted when the competitive edge is greater in comparison to already existing alternatives and when prices are beneficial, implying higher production of forage in an efficient way (Rodrigues et al., 2015). Thus our objective was to investigate the influence of fertilizers on the production, chemical composition and economic parameters of Brachiaria brizantha cv. Marandu (Marandu palisadegrass) and Xaraés (Xaraes palisadegrass) in the short term.

\section{Material and Methods}

The experiment was conducted in greenhouse conditions, utilizing plastic pots $\left(314 \mathrm{~cm}^{2}\right.$ area) containing $7.8 \mathrm{dm}^{3}$ of soil from the $0-20 \mathrm{~cm}$ layer of a Typic Hapludox with clayey texture (EMBRAPA, 2013). The soil has the following chemical characteristics (Silva, 1999): $\mathrm{pH}\left(\mathrm{H}_{2} \mathrm{O}\right)=5.6$; $\mathrm{P}-$ Mehlich $=4 \mathrm{mg} \mathrm{dm}^{-3} ; \mathrm{K}^{+}=94 \mathrm{mg} \mathrm{dm}^{-3}$; $\mathrm{Ca}^{2+}=1.3 \mathrm{cmol}_{\mathrm{c}} \mathrm{dm}^{-3} ; \mathrm{Mg}^{2+}=0.6 \mathrm{cmol}_{\mathrm{c}} \mathrm{dm}^{-3}$; $\mathrm{Al}^{3+}=0.2 \mathrm{cmol}_{\mathrm{c}} \mathrm{dm}^{-3} ; \mathrm{H}+\mathrm{Al}=4 \mathrm{cmol}_{\mathrm{c}} \mathrm{dm}^{-3}$; sum of bases $(\mathrm{SB})=2,2 \mathrm{cmol}_{\mathrm{c}} \mathrm{dm}^{-3}$; CEC potential $=6.2 \mathrm{cmol}_{\mathrm{c}} \mathrm{dm}^{-3}$; base saturation $(\mathrm{V} \%)=36$; aluminum saturation $(\mathrm{m} \%)=8$, and organic matter (O.M.) $=37 \mathrm{~g} \mathrm{~kg}^{-1}$.

The transplantation of Marandu and Xaraes palisadegrass was performed after soil acidity correction with dolomitic lime (11.7 g/pot) and incubation (30 days), using 6 seedlings for pot, previously grown in plastic trays until $5 \mathrm{~cm}$ height. Planting fertilization was not performed, to imitate common pasture implantation practices in Brazil. Soil humidity was maintained at field capacity during the incubation (100\%) and at 70\% during the experimental period. After 30 days from seedling transplantation, a cut for standardization was made at $5 \mathrm{~cm}$ from the soil surface, followed by the first fertilization, according to the treatments. Simple nitrogenous fertilizers of normal release (urea) and slow release (Super $\mathrm{N}$ - urease inhibitor), and compound fertilizers (NPK: 08-28-16, 30-00-20 and 20-10-10) evaluated in three cuts $(60,90$ and 120 days after the transplantation) configured a $5 \times 3$ factorial scheme. Pots were distributed in an entirely randomized design with four replications. 
Rates were applied equivalent to $327 \mathrm{~kg} \mathrm{ha}^{-1}$ urea $(45 \% \mathrm{~N}), 294 \mathrm{~kg} \mathrm{ha}^{-1}$ Super N (45\% N), 350 $\mathrm{kg} \mathrm{ha}^{-1} 08-28-16,333 \mathrm{~kg} \mathrm{ha}^{-1} 30-00-20$ and $357 \mathrm{~kg}$ $\mathrm{ha}^{-1}$ 20-10-10; the capital for fertilizer purchase was adopted as a fixed parameter $(\mathrm{R} \$ 500.00)$ and as standard for rate establishment. The price quotes per ton of fertilizer was made by a specialized resale company (urea - R \$ 1530.00; Super N - R \$ 1700.00; 08-28-16 - R\$ 1430.00; 30-00-20 - R\$1500.00 and 20-10-10 - R\$ 1400.00). Applications were performed at 30, 60 and 90 days after transplantation and corresponded to the supply of $109 \mathrm{~kg} \mathrm{ha}^{-1}$ of urea, $98 \mathrm{~kg} \mathrm{ha}^{-1}$ of Super N, $117 \mathrm{~kg} \mathrm{ha}^{-1}$ of $08-28-16,111$ $\mathrm{kg} \mathrm{ha}^{-1}$ of 30-00-20 and $119 \mathrm{~kg} \mathrm{ha}^{-1}$ of 20-10-10 at each cut time. After the first cut for standardization, cuts were performed at $5 \mathrm{~cm}$ above the soil surface. During plant growth the average temperature was $24.7^{\circ} \mathrm{C}$ and air humidity was $87.7 \%$.

Grass morphological evaluations were made one day before each cut period, while productivity and chemical composition evaluations were made in the material of the cuts made at 60,90 and 120 days after transplantation. Plant height was measured from the plant base to the last recently expanded leaf tip, and the tiller number was counted. The rate of tiller occurrence (RTO) was obtained by the quotient between tiller number and the interval of evaluation (represented by the growth days in each cut). The DMP of leaves and stems were obtained after drying the samples in an oven with forced air circulation at $60^{\circ} \mathrm{C}$ for 72 hours. The sampled plant material was immediately ground in a Wiley type mill with sieve of $1 \mathrm{~mm}$ mesh, and subsequently analyzed.

Dry mass (DM) values and total nitrogen (TN) were determined following the methods proposed by AOAC (1990, methods $N^{\circ} 934.01$ and 976.05, respectively). The $\mathrm{CP}$ content was obtained as $\mathrm{TN}$ $\times 6.25$. Determination of neutral detergent fiber (NDF) and acid detergent fiber (ADF) followed the methods described by Goering and Van Soest (1970). Hemicellulose content was obtained by the difference between NDF and ADF. Total digestible nutrients (TDN), digestible energy (DE) and metabolizable energy (ME) content were calculated according to equations proposed by Rodrigues (2009) as follows: \%TDN $=87.84-(0.7 \times \% \mathrm{ADF})$; $\mathrm{DE}(\mathrm{Mcal} / \mathrm{kg} / \mathrm{DM})=\% \mathrm{TDN} \times 0.04409$, and $\mathrm{ME}$ $(\mathrm{Mcal} / \mathrm{kg} / \mathrm{MS})=\mathrm{ED} \times 0.82$.

Finally, total dry mass production $(\mathrm{TDMP}=$ stem + leaves) was extrapolated to 1 hectare, taking into account the area of the pot for TDMP calculation per kilogram of fertilizer applied and per unit of real (R\$ 1.00). Results were obtained by the quotient of TDMP $\left(\mathrm{kg} \mathrm{ha}^{-1}\right)$ related to the amount of fertilizer applied $\left(\mathrm{kg} \mathrm{ha}^{-1}\right)$ in every cut and capital invested per hectare ( $\mathrm{R} \$ 500.00)$ in the purchase of fertilizers. All data were submitted to analysis of variance with means comparison for fertilizers and for cuts by the Tukey test at $5 \%$ significance.

\section{Results and Discussion}

\section{Marandu palisadegrass}

The fertilizers evaluated did not alter $(\mathrm{p}>0.05)$ height or number of tillers of Marandu palisadegrass, but changes were observed because of cuts (Table 1). Height and tiller number of forage normally increases with fertilization, but the interaction between fertilizer, environment and cut frequency can affect the phenotypic result (Fagundes et al., 2006). Thus this interaction probably promoted greater height values in the first cut and greater tiller number in the third cut (Table 1). There was no interaction of tiller number as a function of the fertilizers, but the rate of tiller occurrence was higher with the supply of urea in the first and second cuts, Super $\mathrm{N}$ in the second and third cuts, and 20-10-10 in the second cut of the Marandu palisadegrass, respectively.

Only fertilized plants with Super N showed changes in the rate of tiller occurrence because of cuts (Table 1), and higher values were observed in the third cut. This can be explained by the activation of dormant buds by nitrogen, accelerating the process of tiller occurrence, which results in higher mass production when environmental conditions are favorable (Martuscello et al., 2006). Greater production of dry mass of leaves and stems was found when plants were fertilized with urea and Super N, taking into account that the rate of $\mathrm{N}$ supplied by these two fertilizers was greater in comparison to the other fertilizers used. Stem dry mass production in the third cut of Marandu palisadegrass fertilized with Super N was greater than two first cuts, which can be attributed to the gradual liberation of $\mathrm{N}$ in the soil solution (Table 1). Costa et al. (2009) verified linear increases of dry mass production of Marandu palisadegrass due to $\mathrm{N}$ supply.

The greatest DM values in leaves of Marandu palisadegrass were obtained with the application of urea in the first and second cuts, 30-00-20 in the 
Table 1. Effect of simple and compound fertilizers on plant height (PH), tiller number (TN), rate of tiller occurrence (RTO) and dry mass production (DMP) of Marandu palisadegrass.

\begin{tabular}{lccccccc}
\hline \multirow{2}{*}{ Variable } & Cut & \multirow{2}{*}{ Tissue } & \multicolumn{5}{c}{ Fertilizers } \\
\cline { 4 - 7 } & & & Urea & Super N & $08-28-16$ & $20-10-10$ & $30-00-20$ \\
\hline \multirow{2}{*}{ PH } & 1 & - & $67.43 \mathrm{aA}$ & $62.01 \mathrm{aA}$ & $53.72 \mathrm{aA}$ & $61.02 \mathrm{aA}$ & $59.52 \mathrm{aA}$ \\
& 2 & - & $47.34 \mathrm{aB}$ & $48.30 \mathrm{aB}$ & $41.54 \mathrm{aB}$ & $47.31 \mathrm{aB}$ & $47.55 \mathrm{aA}$ \\
& 3 & - & $55.40 \mathrm{aAB}$ & $60.62 \mathrm{aA}$ & $48.79 \mathrm{aAB}$ & $47.56 \mathrm{aB}$ & $50.58 \mathrm{aA}$ \\
\hline \multirow{2}{*}{ TN } & 1 & - & $45.00 \mathrm{aB}$ & $40.25 \mathrm{aB}$ & $38.25 \mathrm{aA}$ & $50.50 \mathrm{aB}$ & $45.00 \mathrm{aB}$ \\
& 2 & - & $72.00 \mathrm{aAB}$ & $74.50 \mathrm{aA}$ & $49.25 \mathrm{aA}$ & $74.75 \mathrm{aAB}$ & $68.25 \mathrm{aAB}$ \\
& 3 & - & $85.25 \mathrm{aA}$ & $104.50 \mathrm{aA}$ & $49.50 \mathrm{aA}$ & $83.50 \mathrm{aA}$ & $81.00 \mathrm{aA}$ \\
\hline & 1 & - & $2.19 \mathrm{aA}$ & $2.07 \mathrm{abB}$ & $1.79 \mathrm{bA}$ & $2.03 \mathrm{abA}$ & $1.98 \mathrm{abA}$ \\
$\mathrm{RTO}$ & 2 & - & $2.40 \mathrm{aA}$ & $2.48 \mathrm{aAB}$ & $1.64 \mathrm{bA}$ & $2.49 \mathrm{aA}$ & $2.27 \mathrm{abA}$ \\
& 3 & - & $2.84 \mathrm{bA}$ & $3.48 \mathrm{aA}$ & $1.65 \mathrm{cA}$ & $2.78 \mathrm{bA}$ & $2.70 \mathrm{bA}$ \\
\hline & 1 & & $5.16 \mathrm{aA}$ & $4.28 \mathrm{abA}$ & $2.39 \mathrm{bA}$ & $3.79 \mathrm{abA}$ & $3.90 \mathrm{abA}$ \\
& 2 & Leaf & $4.00 \mathrm{abA}$ & $4.50 \mathrm{aA}$ & $2.25 \mathrm{bA}$ & $3.50 \mathrm{abA}$ & $4.50 \mathrm{aA}$ \\
& 3 & & $5.00 \mathrm{aA}$ & $6.00 \mathrm{aA}$ & $3.25 \mathrm{aA}$ & $3.50 \mathrm{aA}$ & $4.75 \mathrm{aA}$ \\
$\mathrm{DMP}$ & 1 & & $2.09 \mathrm{aA}$ & $2.41 \mathrm{aB}$ & $1.24 \mathrm{aA}$ & $2.24 \mathrm{aA}$ & $2.29 \mathrm{aA}$ \\
& 2 & Stem & $1.75 \mathrm{aA}$ & $2.75 \mathrm{aB}$ & $1.25 \mathrm{aA}$ & $2.00 \mathrm{aA}$ & $2.25 \mathrm{aA}$ \\
& 3 & & $2.75 \mathrm{abA}$ & $4.50 \mathrm{aA}$ & $1.50 \mathrm{bA}$ & $2.00 \mathrm{bA}$ & $2.50 \mathrm{abA}$ \\
\hline
\end{tabular}

PH - plant height (cm); TN - tiller number (units/pot); RTO - rate of tiller occurrence (tillers/day/pot); DMP - dry matter production (g/pot). Means followed by different lowercase letters in the rows and uppercase letters in the columns differ by the Tukey test at 5\% significance.

second cut and Super N in the third cut, respectively (Table 2). In the third cut the highest values of DM were found in the leaves of Marandu palisadegrass, which is associated with the increase of fiber in the third cut. However, fertilizers and cuts did not alter $(p>0.05)$ the stem dry mass. The lowest values of NDF in the leaves were found when urea and Super $\mathrm{N}$ were applied in the first cut, but differences were not detected in NDF in the stems because of the fertilizers. It is known that $\mathrm{N}$ increases amino acids and proteins that accumulate especially into cell content, producing dilution in the cell wall (Van Soest, 1994). The NDF content in the leaves and stems increased in the two last cuts more than in the first (Table 2), once the CP decreased. It must be noted that values of cell wall components above 55\% have a negative correlation with forage consumption (Van Soest, 1994).

The lowest values of ADF in the leaves occurred with the application of urea in the first cut and 08-28-16 in the third cut, and in the stems were found with urea and Super $N$ in the second cut, and 08-28-16 in the second and third cuts (Table 2). The ADF values in Marandu palisadegrass increased in the two latter cuts in relation to the first cut. Applications of Super N, 20-10-10 and 30-00-20 decreased hemicellulose values in the leaves of Marandu palisadegrass in the third cut. In the stems, the lower hemicellulose was verified with 20-10-10 in the second cut. As occurred with NDF, hemicellulose values in leaves were higher in the third cut. The lower ADF and hemicellulose values are possibly related to the higher CP values (Van Soest, 1994), since N, P and K supply are essential for protein synthesis. The results are in concordance with those of other studies, where NDF and ADF decreased with $\mathrm{N}$ supply and increased with the cut sequences (Bennet et al., 2008).

Higher CP in the leaves of Marandu palisadegrass in the first cut was verified with urea (Table 3), since the rate was higher and the $\mathrm{N}$ release possibly was faster in relation to the other fertilizers. The plants showed lower CP content in the leaves in the second and third cuts than the first cut when fertilized with urea, Super $\mathrm{N}$ and 30-00-20, which is associated with the greater fiber content. The $\mathrm{CP}$ content in stems also decreased in the two last cuts compared to the first cut when plants were fertilized with urea, Super $\mathrm{N}, 08-28-16$ and 30-00-20. It must be highlighted that these results could decrease grass digestion because of inadequate levels of $\mathrm{N}$ for the rumen microorganisms (Van Soest, 1994). 
Table 2. Effect of simple and compound fertilizers on dry mass (DM), neutral detergent fiber (NDF), acid detergent fiber (ADF) and hemicellulose (Hem) content in Marandu palisadegrass.

\begin{tabular}{|c|c|c|c|c|c|c|c|}
\hline \multirow{2}{*}{ Variable } & \multirow{2}{*}{ Cut } & \multirow{2}{*}{ Tissue } & \multicolumn{5}{|c|}{ Fertilizers } \\
\hline & & & Urea & Super N & $08-28-16$ & $20-10-10$ & $30-00-20$ \\
\hline \multirow{6}{*}{ DM } & 1 & \multirow{3}{*}{ Leaf } & $24.68 \mathrm{aB}$ & $21.42 \mathrm{abB}$ & $20.40 \mathrm{bB}$ & $22.36 \mathrm{abB}$ & $21.92 \mathrm{abB}$ \\
\hline & 2 & & $24.89 \mathrm{aB}$ & $23.47 \mathrm{abB}$ & $21.42 \mathrm{bAB}$ & $23.89 \mathrm{abAB}$ & $24.72 \mathrm{aB}$ \\
\hline & 3 & & $33.92 \mathrm{abA}$ & $38.74 \mathrm{aA}$ & $26.82 \mathrm{bA}$ & $29.51 \mathrm{abA}$ & $32.51 \mathrm{abA}$ \\
\hline & 1 & \multirow{3}{*}{ Stem } & $19.70 \mathrm{aA}$ & $17.77 \mathrm{aA}$ & $16.97 \mathrm{aA}$ & $18.19 \mathrm{aA}$ & $18.31 \mathrm{aA}$ \\
\hline & 2 & & $19.14 \mathrm{aA}$ & $18.67 \mathrm{aA}$ & $16.35 \mathrm{aA}$ & $18.41 \mathrm{aA}$ & $19.47 \mathrm{aA}$ \\
\hline & 3 & & $20.67 \mathrm{aA}$ & $20.41 \mathrm{aA}$ & $15.97 \mathrm{aA}$ & $18.05 \mathrm{aA}$ & $20.38 \mathrm{aA}$ \\
\hline \multirow{6}{*}{ NDF } & 1 & \multirow{3}{*}{ Leaf } & $48.04 \mathrm{bB}$ & $47.25 \mathrm{bB}$ & $54.03 \mathrm{aB}$ & $53.29 \mathrm{aB}$ & $52.24 \mathrm{aB}$ \\
\hline & 2 & & $61.24 \mathrm{aA}$ & $59.19 \mathrm{aA}$ & $61.41 \mathrm{aA}$ & $54.52 \mathrm{aB}$ & $60.53 \mathrm{aA}$ \\
\hline & 3 & & $60.74 \mathrm{aA}$ & $59.12 \mathrm{aA}$ & $62.36 \mathrm{aA}$ & $62.28 \mathrm{aA}$ & $61.28 \mathrm{aA}$ \\
\hline & 1 & \multirow{3}{*}{ Stem } & $57.72 \mathrm{aC}$ & $58.60 \mathrm{aB}$ & $62.02 \mathrm{aB}$ & $60.83 \mathrm{aB}$ & $59.47 \mathrm{aC}$ \\
\hline & 2 & & $64.69 \mathrm{aB}$ & $65.99 \mathrm{aA}$ & $66.92 \mathrm{aA}$ & $66.07 \mathrm{aA}$ & $67.49 \mathrm{aB}$ \\
\hline & 3 & & $69.80 \mathrm{aA}$ & $69.38 \mathrm{aA}$ & $66.84 \mathrm{aA}$ & $66.70 \mathrm{aA}$ & $71.30 \mathrm{aA}$ \\
\hline \multirow{6}{*}{$\mathrm{ADF}$} & 1 & \multirow{3}{*}{ Leaf } & $26.23 \mathrm{bB}$ & $27.06 \mathrm{abB}$ & $31.45 \mathrm{aA}$ & $30.16 \mathrm{abB}$ & $29.38 \mathrm{abB}$ \\
\hline & 2 & & $30.76 \mathrm{aA}$ & $32.66 \mathrm{aA}$ & $33.29 \mathrm{aA}$ & $32.1 \mathrm{aAB}$ & $34.62 \mathrm{aA}$ \\
\hline & 3 & & $31.42 \mathrm{abA}$ & $32.77 \mathrm{abA}$ & $27.19 \mathrm{bB}$ & $36.53 \mathrm{aA}$ & $34.76 \mathrm{aA}$ \\
\hline & 1 & \multirow{3}{*}{ Stem } & $37.53 \mathrm{aA}$ & $38.18 \mathrm{aA}$ & $38.43 \mathrm{aA}$ & $38.72 \mathrm{aB}$ & $39.63 \mathrm{aB}$ \\
\hline & 2 & & $38.05 \mathrm{bA}$ & $39.03 \mathrm{bA}$ & $38.65 \mathrm{bA}$ & $47.01 \mathrm{aA}$ & 40.04 bB \\
\hline & 3 & & $43.00 \mathrm{abA}$ & $43.20 \mathrm{abA}$ & $36.13 \mathrm{bA}$ & $41.69 \mathrm{abAB}$ & $51.43 \mathrm{aA}$ \\
\hline \multirow{6}{*}{ Hem } & 1 & \multirow{3}{*}{ Leafe } & $21.81 \mathrm{aB}$ & $20.18 \mathrm{aB}$ & $22.57 \mathrm{aB}$ & $23.12 \mathrm{aA}$ & $22.86 \mathrm{aA}$ \\
\hline & 2 & & $30.48 \mathrm{aA}$ & $26.53 \mathrm{aA}$ & $28.11 \mathrm{aB}$ & $21.81 \mathrm{aA}$ & $25.90 \mathrm{aA}$ \\
\hline & 3 & & $29.31 \mathrm{abA}$ & $26.35 \mathrm{bA}$ & $35.16 \mathrm{aA}$ & $25.74 \mathrm{bA}$ & $26.51 \mathrm{bA}$ \\
\hline & 1 & \multirow{3}{*}{ Stem } & $20.18 \mathrm{aA}$ & $20.42 \mathrm{aA}$ & $23.58 \mathrm{aA}$ & $22.11 \mathrm{aA}$ & $19.84 \mathrm{aB}$ \\
\hline & 2 & & $26.64 \mathrm{abA}$ & $26.95 \mathrm{aA}$ & $28.27 \mathrm{aA}$ & $19.07 \mathrm{bA}$ & $27.45 \mathrm{aA}$ \\
\hline & 3 & & $26.79 \mathrm{aA}$ & $26.17 \mathrm{aA}$ & $30.81 \mathrm{aA}$ & $25.00 \mathrm{aA}$ & $19.87 \mathrm{aB}$ \\
\hline
\end{tabular}

DM-dry mass (\%); NDF-neutral detergent fiber (\%); ADF-acid detergent fiber (\%); Hem - hemicellulose (\%). Means followed by different lowercase letters in the rows and uppercase letters in the columns differ by the Tukey test at $5 \%$ significance.

The TDN, DE and ME values in the leaves were higher with urea utilization in the first cut and with 08-28-16 in the third cut (Table 3). The increase in energetic content of Marandu palisadegrass due to urea application may be associated with greater amounts of rapidly degraded polymers such as cellulose, due to the high rate of N (Van Soest, 1994), whereas 08-28-16 application resulted in greater $\mathrm{P}$ availability, that performs important functions in the transference of energy in plant cells (Sousa et al., 2010). The TDN, DE and ME content in leaves and stems of Marandu palisadegrass fertilized with urea, Super N and 30-00-20 decreased in the two last cuts in comparison to the first cut (Table 3), possibly because of an increase in the fibrous fractions of low degradability content and $\mathrm{CP}$ content reduction. These results are in concordance with other studies, where the TDN of Marandu palisadegrass was higher with $\mathrm{N}$ supply and declined with the successive cuts (Benett et al., 2008). Similarly, higher rates of $\mathrm{N}$ and $\mathrm{P}$ resulted in higher TDN of Tanzania guineagrass (Sousa et al., 2010).

Supplying Super N to Marandu palisadegrass resulted in more total DM production per kilogram of fertilizers utilized in comparison to the other fertilizers, in the three cuts performed (Table 4). It is important to highlight that the total DM production in this treatment increased gradually with the subsequent cuts, demonstrating the beneficial effect of enhanced fertilizer use. Higher values of TDMP per unit of real (R\$) invested were found with urea utilization in the first cut and Super $\mathrm{N}$ in the second and third cuts. Supplying only Super $\mathrm{N}$ resulted in increases of production with the sequence of cuts. According to Dupas et al. (2016a,b), nitrogenous fertilization is responsible for production sustainability in pastures and might be a viable economic alternative for beef cattle production, especially when the other nutrients are supplied adequately. 
Table 3. Effect of simple and compounds fertilizers in crude protein (CP), total digestible nutrients (TDN), digestible energy (DE) and metabolizable energy (ME) of Marandu palisadegrass.

\begin{tabular}{|c|c|c|c|c|c|c|c|}
\hline \multirow{2}{*}{ Variable } & \multirow{2}{*}{ Cut } & \multirow{2}{*}{ Tissue } & \multicolumn{5}{|c|}{ Fertilizers } \\
\hline & & & Urea & Super N & 08-28-16 & $20-10-10$ & $30-00-20$ \\
\hline \multirow{6}{*}{$\mathrm{CP}$} & 1 & \multirow{3}{*}{ Leaf } & $14.70 \mathrm{aA}$ & $14.04 \mathrm{abA}$ & $11.90 \mathrm{bA}$ & $11.83 \mathrm{bA}$ & $12.00 \mathrm{bA}$ \\
\hline & 2 & & $12.80 \mathrm{aAB}$ & $11.79 \mathrm{aB}$ & $11.95 \mathrm{aA}$ & $10.98 \mathrm{aA}$ & $10.61 \mathrm{aAB}$ \\
\hline & 3 & & $11.11 \mathrm{aB}$ & $9.71 \mathrm{aB}$ & $11.10 \mathrm{aA}$ & $10.44 \mathrm{aA}$ & $9.26 \mathrm{aB}$ \\
\hline & 1 & \multirow{3}{*}{ Stem } & $8.27 \mathrm{aA}$ & $7.84 \mathrm{aA}$ & $8.27 \mathrm{aA}$ & $6.94 \mathrm{aA}$ & $7.27 \mathrm{aA}$ \\
\hline & 2 & & $7.24 \mathrm{aA}$ & $7.05 \mathrm{aA}$ & $6.58 \mathrm{aB}$ & $6.68 \mathrm{aA}$ & $5.77 \mathrm{aB}$ \\
\hline & 3 & & $5.48 \mathrm{aB}$ & $4.92 \mathrm{aB}$ & $5.45 \mathrm{aB}$ & $6.19 \mathrm{aA}$ & $5.06 \mathrm{aB}$ \\
\hline \multirow{6}{*}{ TDN } & 1 & \multirow{3}{*}{ Leaf } & $69.48 \mathrm{aA}$ & $68.89 \mathrm{abA}$ & $65.81 \mathrm{bB}$ & $66.72 \mathrm{abA}$ & $67.27 \mathrm{abA}$ \\
\hline & 2 & & $66.30 \mathrm{aB}$ & $64.98 \mathrm{aB}$ & $64.52 \mathrm{aB}$ & $64.94 \mathrm{aAB}$ & $63.60 \mathrm{aB}$ \\
\hline & 3 & & $65.84 \mathrm{abB}$ & $64.90 \mathrm{abB}$ & $68.80 \mathrm{aA}$ & $62.26 \mathrm{bB}$ & $63.50 \mathrm{bB}$ \\
\hline & 1 & \multirow{3}{*}{ Stem } & $61.56 \mathrm{aA}$ & $61.11 \mathrm{aA}$ & $60.93 \mathrm{aA}$ & $60.73 \mathrm{aA}$ & $60.09 \mathrm{aA}$ \\
\hline & 2 & & $61.20 \mathrm{aA}$ & $60.51 \mathrm{aA}$ & $60.78 \mathrm{aA}$ & $54.93 \mathrm{bB}$ & $59.81 \mathrm{aA}$ \\
\hline & 3 & & $57.73 \mathrm{abA}$ & $57.59 \mathrm{abA}$ & $62.54 \mathrm{aA}$ & $58.65 \mathrm{abAB}$ & $51.83 \mathrm{bB}$ \\
\hline \multirow{6}{*}{ DE } & 1 & \multirow{3}{*}{ Leaf } & $3.06 \mathrm{aA}$ & $3.03 \mathrm{abA}$ & $2.90 \mathrm{bB}$ & $2.94 \mathrm{abA}$ & $2.96 \mathrm{abA}$ \\
\hline & 2 & & $2.92 \mathrm{aB}$ & $2.86 \mathrm{aB}$ & $2.84 \mathrm{aB}$ & $2.86 \mathrm{aAB}$ & $2.80 \mathrm{aB}$ \\
\hline & 3 & & $2.90 \mathrm{abB}$ & $2.86 \mathrm{abB}$ & $3.03 \mathrm{aA}$ & $2.74 \mathrm{bB}$ & $2.79 \mathrm{bB}$ \\
\hline & 1 & \multirow{3}{*}{ Stem } & $2.71 \mathrm{aA}$ & $2.69 \mathrm{aA}$ & $2.68 \mathrm{aA}$ & $2.67 \mathrm{aA}$ & $2.64 \mathrm{aA}$ \\
\hline & 2 & & $2.69 \mathrm{aA}$ & $2.66 \mathrm{aA}$ & $2.67 \mathrm{aA}$ & $2.42 \mathrm{bB}$ & $2.63 \mathrm{aA}$ \\
\hline & 3 & & $2.54 \mathrm{abA}$ & $2.53 \mathrm{abA}$ & $2.75 \mathrm{aA}$ & $2.58 \mathrm{abA}$ & $2.28 \mathrm{bB}$ \\
\hline \multirow{6}{*}{ ME } & 1 & \multirow{3}{*}{ Leaf } & $2.51 \mathrm{aA}$ & $2.49 \mathrm{abA}$ & $2.37 \mathrm{bB}$ & $2.41 \mathrm{abA}$ & $2.43 \mathrm{abA}$ \\
\hline & 2 & & $2.39 \mathrm{aB}$ & $2.34 \mathrm{aB}$ & $2.33 \mathrm{aB}$ & $2.34 \mathrm{aAB}$ & $2.29 \mathrm{aB}$ \\
\hline & 3 & & $2.38 \mathrm{abB}$ & $2.34 \mathrm{abB}$ & $2.48 \mathrm{aA}$ & $2.25 \mathrm{bB}$ & $2.29 \mathrm{bB}$ \\
\hline & 1 & \multirow{3}{*}{ Stem } & $2.22 \mathrm{aA}$ & $2.20 \mathrm{aA}$ & $2.20 \mathrm{aA}$ & $2.19 \mathrm{aA}$ & $2.17 \mathrm{aA}$ \\
\hline & 2 & & $2.21 \mathrm{aA}$ & $2.18 \mathrm{aA}$ & $2.19 \mathrm{aA}$ & $1.98 \mathrm{bB}$ & $2.16 \mathrm{aA}$ \\
\hline & 3 & & $2.08 \mathrm{abA}$ & $2.08 \mathrm{abA}$ & $2.26 \mathrm{aA}$ & $2.12 \mathrm{abA}$ & $1.87 \mathrm{bB}$ \\
\hline
\end{tabular}

CP-crude protein (\%); TDN-total digestible nutrient (\%); DE-digestible energy (Mcal/kg/DM); ME - metabolizable energy (Mcal $/ \mathrm{kg} / \mathrm{MS})$. Means followed by different lowercase letters in the rows and uppercase letters in the columns differ by the Tukey test at $5 \%$ significance.

Table 4. Total dry mass production (TDMP) of Marandu palisadegrass per kilogram of fertilizer $\left(\mathrm{kg} \mathrm{kg}^{-1}\right)$ and per unit of real $(\mathrm{kg} / \mathrm{R} \$ 1.00)$ invested per hectare.

\begin{tabular}{lcccccc}
\hline \multirow{2}{*}{ Variable } & Cut & \multicolumn{5}{c}{ Fertilizers } \\
\cline { 3 - 6 } & & Urea & Super N & $08-28-16$ & $20-10-10$ & $30-00-20$ \\
\cline { 3 - 6 } & 1 & $21.18 \mathrm{aA}$ & $21.72 \mathrm{aB}$ & $9.90 \mathrm{bA}$ & $17.28 \mathrm{abA}$ & $16.59 \mathrm{abA}$ \\
TDMP $\left(\mathrm{kg} \mathrm{kg}^{-1}\right)$ & 2 & $16.83 \mathrm{abA}$ & $23.10 \mathrm{aB}$ & $8.49 \mathrm{bA}$ & $16.11 \mathrm{abA}$ & $17.04 \mathrm{abA}$ \\
& 3 & $22.14 \mathrm{abA}$ & $34.86 \mathrm{aA}$ & $13.14 \mathrm{bA}$ & $15.60 \mathrm{bA}$ & $18.84 \mathrm{abA}$ \\
\hline \multirow{2}{*}{ TDMP $(\mathrm{kg} / \mathrm{R} \$ 1.00)$} & 1 & $13.83 \mathrm{aA}$ & $12.78 \mathrm{abB}$ & $6.93 \mathrm{bA}$ & $11.52 \mathrm{abA}$ & $11.82 \mathrm{abA}$ \\
& 2 & $11.01 \mathrm{abA}$ & $13.56 \mathrm{aB}$ & $5.94 \mathrm{bA}$ & $10.71 \mathrm{abA}$ & $12.15 \mathrm{abA}$ \\
& 3 & $14.49 \mathrm{abA}$ & $20.49 \mathrm{aA}$ & $9.21 \mathrm{bA}$ & $10.38 \mathrm{abA}$ & $13.47 \mathrm{abA}$ \\
\hline
\end{tabular}

TDMP -total dry mass production $\left(\mathrm{kg} \mathrm{ha}^{-1}\right)$. Means followed by different lowercase letters in the rows and uppercase letters in the columns differ by the Tukey test at $5 \%$ significance.

\section{Xaraes palisadegrass}

Xaraes palisadegrass height was not changed $(\mathrm{p}>0.05$ ) by the fertilizers and cut periods (Table 5). However, supplying 20-10-10 increased the number of tillers in the first cut compared to other fertilizers, indicating that Xaraes palisadegrass may be more exigent than the Marandu palisadegrass in $\mathrm{P}$ and $\mathrm{K}$ to produce tillers. Higher tiller numbers were found in the third cut of Xaraes palisadegrass with 08-28-16, 20-10-10 and 30-00-20 compared to the two first cuts. 
Higher rates of tiller occurrence in Xaraes palisadegrass were found with the utilization of Super N in the first cut, 08-28-16 in the first and third cuts and 20-10-10 in all three cuts (Table 5). The rates of tiller occurrence were higher in the third cut of plants fertilized with 08-28-16, 20-1010 and 30-00-20, as occurred for the tiller number, demonstrating that the demand for $\mathrm{P}$ and $\mathrm{K}$ for tiller production by Xaraes palisadegrass may be greater than Marandu palisadegrass. Leaf and stem DM production of Xaraes palisadegrass did not differ ( $p>0.05$ ) with fertilizer or cuts. These results suggest that the higher tiller number of Xaraes palisadegrass lowered tiller weight, impacting mass production similarly in plants with higher and lower tiller production (Santos et al., 2011). Thus mass production of Xaraes palisadegrass can be altered by the different formulations and rates of NPK (Teles et al., 2011).

The DM content in leaves and stems of Xaraes palisadegrass was not changed ( $p>0.05$ ) by the fertilizers, but was changed by the cut periods (Table 6). The highest DM content was found in the third cut, as occurred with Marandu palisadegrass. Lower NDF content in the leaves of Xaraes palisadegrass was found in the second cut with 30-00-20, while Super N, 08-28-16, 20$10-10$ and $30-00-20$ produced lower NDF values of the stem in the third cut. The lowest ADF in the stem was observed with the application of urea in the first cut. Leaf and stem ADF values were higher in the third cut, except for ADF values of plants fertilized with 30-00-20. The hemicellulose content in the stems of plants fertilized with Super $\mathrm{N}$ in the first cut was lower compared to the plants fertilized with other nutrient sources. Lower values of ADF (cellulose and lignin) and hemicellulose were observed with the use of nitrogenous fertilizers, which concurs with results reported by Costa et al. (2009).

The results observed for Xaraes palisadegrass were similar to those found for Marandu palisadegrass fertilized with urea. The higher values of $\mathrm{CP}$ in the leaves and stems of Xaraes palisadegrass in the first and third cuts occurred with the application of urea (Table 7). The CP values decreased in the last two cuts compared to the first cut (Table 7). The TDN, DE and ME content was significantly changed $(p<0.05)$ only in the stem fraction when the plants were fertilized with urea in the first cut, and decreased in the two last cuts compared to the first cut. The results found

Table 5. Effect of simple and compound fertilizers on plant height (PH), tiller number (TN), rate of tiller occurrence (RTO) and dry mass production (DMP) of the Xaraes palisadegrass.

\begin{tabular}{|c|c|c|c|c|c|c|c|}
\hline \multirow{2}{*}{ Variable } & \multirow{2}{*}{ Cut } & \multirow{2}{*}{ Tissue } & \multicolumn{5}{|c|}{ Fertilizers } \\
\hline & & & Urea & Super N & $08-28-16$ & $20-10-10$ & $30-00-20$ \\
\hline \multirow{3}{*}{$\mathrm{PH}$} & 1 & - & $59.76 \mathrm{aA}$ & $60.58 \mathrm{aA}$ & $53.92 \mathrm{aA}$ & $56.12 \mathrm{aA}$ & $65.70 \mathrm{aA}$ \\
\hline & 2 & - & $61.08 \mathrm{aA}$ & $56.60 \mathrm{aA}$ & $59.57 \mathrm{aA}$ & $59.15 \mathrm{aA}$ & $64.20 \mathrm{aA}$ \\
\hline & 3 & - & $63.34 \mathrm{aA}$ & $59.38 \mathrm{aA}$ & $62.70 \mathrm{aA}$ & $64.25 \mathrm{aA}$ & $69.46 \mathrm{aA}$ \\
\hline \multirow{3}{*}{$\mathrm{TN}$} & 1 & - & $24.50 \mathrm{cA}$ & $36.00 \mathrm{abA}$ & $35.75 \mathrm{abB}$ & $39.00 \mathrm{aB}$ & $30.00 \mathrm{bcB}$ \\
\hline & 2 & - & $37.00 \mathrm{aA}$ & $49.00 \mathrm{aA}$ & $45.25 \mathrm{aAB}$ & $54.00 \mathrm{aAB}$ & $48.25 \mathrm{aAB}$ \\
\hline & 3 & - & $41.50 \mathrm{aA}$ & $55.00 \mathrm{aA}$ & $64.25 \mathrm{aA}$ & $63.75 \mathrm{aA}$ & $62.25 \mathrm{aA}$ \\
\hline \multirow{3}{*}{ RTO } & 1 & - & $0.81 \mathrm{bA}$ & $1.20 \mathrm{aA}$ & $1.19 \mathrm{aB}$ & $1.30 \mathrm{aB}$ & $0.99 \mathrm{abB}$ \\
\hline & 2 & - & $1.23 \mathrm{bA}$ & $1.63 \mathrm{abA}$ & $1.50 \mathrm{abAB}$ & $1.80 \mathrm{aAB}$ & $1.60 \mathrm{abAB}$ \\
\hline & 3 & - & $1.38 \mathrm{cA}$ & $1.83 \mathrm{bA}$ & $2.14 \mathrm{aA}$ & $2.12 \mathrm{aA}$ & $2.07 \mathrm{abA}$ \\
\hline \multirow{6}{*}{ DMP } & 1 & \multirow{3}{*}{ Leaf } & $3.50 \mathrm{aA}$ & $4.00 \mathrm{aA}$ & $4.25 \mathrm{aA}$ & $4.75 \mathrm{aA}$ & $5.50 \mathrm{aA}$ \\
\hline & 2 & & $4.75 \mathrm{aA}$ & $5.25 \mathrm{aA}$ & $6.00 \mathrm{aA}$ & $6.25 \mathrm{aA}$ & $6.75 \mathrm{aA}$ \\
\hline & 3 & & $5.00 \mathrm{aA}$ & $5.00 \mathrm{aA}$ & $6.50 \mathrm{aA}$ & $7.00 \mathrm{aA}$ & $7.25 \mathrm{aA}$ \\
\hline & 1 & \multirow{3}{*}{ Stem } & $1.00 \mathrm{aA}$ & $1.25 \mathrm{aA}$ & $1.25 \mathrm{aA}$ & $1.50 \mathrm{aA}$ & $1.75 \mathrm{aA}$ \\
\hline & 2 & & $1.50 \mathrm{aA}$ & $1.75 \mathrm{aA}$ & $2.25 \mathrm{aA}$ & $2.50 \mathrm{aA}$ & $2.50 \mathrm{aA}$ \\
\hline & 3 & & $1.50 \mathrm{aA}$ & $2.00 \mathrm{aA}$ & $2.50 \mathrm{aA}$ & $3.00 \mathrm{aA}$ & $3.00 \mathrm{aA}$ \\
\hline
\end{tabular}

PH - plant height (cm); TN - tillers number (unities/pot); RTO - rate of tillers occurrence (tillers/day/pots); DMP - dry matter production (g/pot). Means followed by different lowercase letters in the rows and uppercase letters in the columns differ by the Tukey test at 5\% significance. 
Table 6. Effect of simple and compound fertilizers on dry mass (DM), neutral detergent fiber (NDF), acid detergent fiber (ADF) and hemicellulose (Hem) content in Xaraes palisadegrass.

\begin{tabular}{|c|c|c|c|c|c|c|c|}
\hline \multirow{2}{*}{ Variable } & \multirow{2}{*}{ Cut } & \multirow{2}{*}{ Tissue } & \multicolumn{5}{|c|}{ Fertilizers } \\
\hline & & & Urea & Super N & $08-28-16$ & $20-10-10$ & $30-00-20$ \\
\hline \multirow{6}{*}{$\mathrm{DM}$} & 1 & \multirow{3}{*}{ Leaf } & $26.48 \mathrm{aB}$ & $22.79 \mathrm{aB}$ & $25.56 \mathrm{aB}$ & $26.49 \mathrm{aB}$ & $26.52 \mathrm{aB}$ \\
\hline & 2 & & $26.86 \mathrm{aB}$ & $25.93 \mathrm{aB}$ & $24.78 \mathrm{aB}$ & $25.10 \mathrm{aB}$ & $25.92 \mathrm{aB}$ \\
\hline & 3 & & $49.63 \mathrm{aA}$ & $46.99 \mathrm{aA}$ & $44.08 \mathrm{aA}$ & $42.14 \mathrm{aA}$ & $42.11 \mathrm{aA}$ \\
\hline & 1 & \multirow{3}{*}{ Stem } & $18.86 \mathrm{aB}$ & $17.09 \mathrm{aB}$ & $18.74 \mathrm{aB}$ & $19.46 \mathrm{aB}$ & $19.20 \mathrm{aB}$ \\
\hline & 2 & & $19.74 \mathrm{aB}$ & $18.80 \mathrm{aB}$ & $18.25 \mathrm{aB}$ & $20.21 \mathrm{aB}$ & $19.67 \mathrm{aB}$ \\
\hline & 3 & & $31.01 \mathrm{aA}$ & $30.39 \mathrm{aA}$ & $30.99 \mathrm{aA}$ & $30.72 \mathrm{aA}$ & $31.12 \mathrm{aA}$ \\
\hline \multirow{6}{*}{$\mathrm{NDF}$} & 1 & \multirow{3}{*}{ Leaf } & $50.00 \mathrm{aB}$ & $51.17 \mathrm{aB}$ & $52.20 \mathrm{aB}$ & $53.21 \mathrm{aB}$ & $52.10 \mathrm{aB}$ \\
\hline & 2 & & $62.31 \mathrm{aA}$ & $59.75 \mathrm{abA}$ & $60.79 \mathrm{abA}$ & 61.61abA & $59.24 \mathrm{bA}$ \\
\hline & 3 & & $59.85 \mathrm{aA}$ & $62.20 \mathrm{aA}$ & $61.21 \mathrm{aA}$ & $59.90 \mathrm{aA}$ & $58.08 \mathrm{aA}$ \\
\hline & 1 & \multirow{3}{*}{ Stem } & $58.71 \mathrm{aC}$ & $58.42 \mathrm{aB}$ & $59.93 \mathrm{aB}$ & $60.11 \mathrm{aB}$ & $62.10 \mathrm{aB}$ \\
\hline & 2 & & $68.08 \mathrm{aB}$ & $66.63 \mathrm{aA}$ & $68.03 \mathrm{aA}$ & $69.21 \mathrm{aA}$ & $68.72 \mathrm{aA}$ \\
\hline & 3 & & $72.82 \mathrm{aA}$ & $69.97 \mathrm{bA}$ & $69.71 \mathrm{bA}$ & $69.51 \mathrm{bA}$ & $69.25 \mathrm{bA}$ \\
\hline \multirow{6}{*}{$\mathrm{ADF}$} & 1 & \multirow{3}{*}{ Leaf } & $27.33 \mathrm{aB}$ & $27.63 \mathrm{aB}$ & $33.02 \mathrm{aA}$ & $29.15 \mathrm{aA}$ & $32.08 \mathrm{aA}$ \\
\hline & 2 & & $38.62 \mathrm{aA}$ & $32.95 \mathrm{aB}$ & $34.89 \mathrm{aA}$ & $34.10 \mathrm{aA}$ & $33.66 \mathrm{aA}$ \\
\hline & 3 & & $38.57 \mathrm{aA}$ & $42.14 \mathrm{aA}$ & $40.60 \mathrm{aA}$ & $35.41 \mathrm{aA}$ & $34.99 \mathrm{aA}$ \\
\hline & 1 & \multirow{3}{*}{ Stem } & $32.83 \mathrm{~dB}$ & $40.86 \mathrm{abA}$ & $39.87 \mathrm{bB}$ & $36.34 \mathrm{cB}$ & $41.94 \mathrm{aA}$ \\
\hline & 2 & & $44.69 \mathrm{aA}$ & $43.14 \mathrm{aA}$ & $42.59 \mathrm{aAB}$ & $42.01 \mathrm{aAB}$ & $42.25 \mathrm{aA}$ \\
\hline & 3 & & $49.34 \mathrm{aA}$ & $44.19 \mathrm{aA}$ & $48.77 \mathrm{aA}$ & $45.44 \mathrm{aA}$ & $46.49 \mathrm{aA}$ \\
\hline \multirow{6}{*}{ Hem } & 1 & \multirow{3}{*}{ Leaf } & $22.67 \mathrm{aA}$ & $23.54 \mathrm{aA}$ & $19.17 \mathrm{aA}$ & $24.06 \mathrm{aA}$ & $20.01 \mathrm{aA}$ \\
\hline & 2 & & $23.69 \mathrm{aA}$ & $26.81 \mathrm{aA}$ & $25.89 \mathrm{aA}$ & $27.50 \mathrm{aA}$ & $25.57 \mathrm{aA}$ \\
\hline & 3 & & $21.28 \mathrm{aA}$ & $20.06 \mathrm{aA}$ & $20.61 \mathrm{aA}$ & $24.48 \mathrm{aA}$ & $23.08 \mathrm{aA}$ \\
\hline & 1 & \multirow{3}{*}{ Stem } & $25.88 \mathrm{aA}$ & $17.56 \mathrm{bB}$ & $20.06 \mathrm{abA}$ & $23.77 \mathrm{abA}$ & $20.15 \mathrm{abA}$ \\
\hline & 2 & & $23.38 \mathrm{aA}$ & $23.48 \mathrm{aAB}$ & $25.44 \mathrm{aA}$ & $27.19 \mathrm{aA}$ & $26.47 \mathrm{aA}$ \\
\hline & 3 & & $23.48 \mathrm{aA}$ & $25.78 \mathrm{aA}$ & $20.93 \mathrm{aA}$ & $24.06 \mathrm{aA}$ & $22.75 \mathrm{aA}$ \\
\hline
\end{tabular}

DM - dry mass (\%); NDF - neutral detergent fiber (\%); ADF - acid detergent fiber (\%); Hem - hemicellulose $(\%)$. Means followed by different lowercase letters in the rows and uppercase letters in the columns differ by the Tukey test at $5 \%$ significance.

in this study help to corroborate data from other studies that reported an increment in the $\mathrm{CP}$ and TDN of Xaraes palisadegrass with application of urea as N source (Costa et al., 2013).

The TDMP of Xaraes palisadegrass per kilogram of fertilizer applied and per unit of real (R\$) invested did not significantly differ as a function of the nutrient sources utilized or the periods of cuts (Table 8), showing once again that Xaraes palisadegrass can be more exigent for $\mathrm{P}$ and $\mathrm{K}$ than Marandu palisadegrass.

\section{Conclusions}

The supply of nitrogenous fertilizers increased tiller production of Marandu palisadegrass and resulted in more desirable chemical composition for ruminant nutrition. Fertilization with Super N in forage of Marandu palisadegrass is more efficient from the productive and economic point of view than fertilization with conventional urea.

Differences between simple and compound fertilizers were less marked in Xaraes palisadegrass, but it must be highlighted that the supply of urea and 20-10-10 resulted in better chemical composition for ruminant nutrition. Xaraes palisadegrass is more exigent in $\mathrm{P}$ and $\mathrm{K}$ than Marandu palisadegrass.

It is important to note that fertilization of forages with nitrogenous fertilizers and NPK formulations is not enough to increase and/or maintain the productivity efficiency of pastures in longer periods if other nutrients are not supplied to the plants. 
Table 7. Effect of simple and compound fertilizers on crude protein (CP), total digestible nutrients (TDN), digestible energy (DE) and metabolizable energy (ME) of the Xaraes palisadegrass.

\begin{tabular}{|c|c|c|c|c|c|c|c|}
\hline \multirow{2}{*}{ Variable } & \multirow{2}{*}{ Cut } & \multirow{2}{*}{ Tissue } & \multicolumn{5}{|c|}{ Fertilizers } \\
\hline & & & Urea & Super N & 08-28-16 & 20-10-10 & $30-00-20$ \\
\hline \multirow{6}{*}{$\mathrm{CP}$} & 1 & \multirow{3}{*}{ Leaf } & $14.36 \mathrm{aA}$ & $13.55 \mathrm{abA}$ & $11.76 \mathrm{bA}$ & $11.57 \mathrm{bA}$ & $12.23 \mathrm{abA}$ \\
\hline & 2 & & $10.83 \mathrm{aB}$ & $11.05 \mathrm{aB}$ & $8.40 \mathrm{aB}$ & $8.41 \mathrm{aB}$ & $9.87 \mathrm{aB}$ \\
\hline & 3 & & $11.14 \mathrm{aB}$ & $10.10 \mathrm{aB}$ & $6.77 \mathrm{cB}$ & $7.65 \mathrm{bcB}$ & $9.40 \mathrm{abB}$ \\
\hline & 1 & \multirow{3}{*}{ Stem } & $11.68 \mathrm{aA}$ & 10.31abA & $5.83 \mathrm{cA}$ & $8.07 \mathrm{bcA}$ & $7.83 \mathrm{bcA}$ \\
\hline & 2 & & $6.49 \mathrm{aB}$ & $6.66 \mathrm{aB}$ & $4.27 \mathrm{aA}$ & $4.86 \mathrm{aB}$ & $6.21 \mathrm{aAB}$ \\
\hline & 3 & & $6.97 \mathrm{aB}$ & $5.28 \mathrm{bB}$ & $3.64 \mathrm{cA}$ & $4.40 \mathrm{bcB}$ & $4.43 \mathrm{bcB}$ \\
\hline \multirow{6}{*}{ TDN } & 1 & \multirow{3}{*}{ Leaf } & $68.70 \mathrm{aA}$ & $68.50 \mathrm{aA}$ & $64.72 \mathrm{aA}$ & $67.43 \mathrm{aA}$ & $65.38 \mathrm{aA}$ \\
\hline & 2 & & $60.80 \mathrm{aB}$ & $64.77 \mathrm{aA}$ & $63.41 \mathrm{aA}$ & $63.96 \mathrm{aA}$ & $64.27 \mathrm{aA}$ \\
\hline & 3 & & $60.84 \mathrm{aB}$ & $58.34 \mathrm{aB}$ & $59.42 \mathrm{aA}$ & $63.04 \mathrm{aA}$ & $63.34 \mathrm{aA}$ \\
\hline & 1 & \multirow{3}{*}{ Stem } & $64.86 \mathrm{aA}$ & $59.23 \mathrm{cdA}$ & $59.93 \mathrm{cA}$ & $62.40 \mathrm{bA}$ & $58.48 \mathrm{dA}$ \\
\hline & 2 & & $56.55 \mathrm{aB}$ & $57.63 \mathrm{aA}$ & $58.02 \mathrm{aAB}$ & $58.42 \mathrm{aAB}$ & $58.26 \mathrm{aA}$ \\
\hline & 3 & & $53.30 \mathrm{aB}$ & $56.90 \mathrm{aA}$ & $53.69 \mathrm{aB}$ & $56.03 \mathrm{aB}$ & $55.29 \mathrm{aA}$ \\
\hline \multirow{6}{*}{$\mathrm{DE}$} & 1 & \multirow{3}{*}{ Leaf } & $3.02 \mathrm{aA}$ & $3.02 \mathrm{aA}$ & $2.85 \mathrm{aA}$ & $2.97 \mathrm{aA}$ & $2.88 \mathrm{aA}$ \\
\hline & 2 & & $2.68 \mathrm{aB}$ & $2.85 \mathrm{aAB}$ & $2.79 \mathrm{aAB}$ & $2.82 \mathrm{aB}$ & $2.83 \mathrm{aAB}$ \\
\hline & 3 & & $2.68 \mathrm{aB}$ & $2.57 \mathrm{aB}$ & $2.61 \mathrm{aB}$ & $2.77 \mathrm{aB}$ & $2.79 \mathrm{aB}$ \\
\hline & 1 & \multirow{3}{*}{ Stem } & $2.85 \mathrm{aA}$ & $2.61 \mathrm{cdA}$ & $2.64 \mathrm{cA}$ & $2.75 \mathrm{bA}$ & $2.57 \mathrm{dA}$ \\
\hline & 2 & & $2.49 \mathrm{aAB}$ & $2.54 \mathrm{aA}$ & $2.55 \mathrm{aA}$ & $2.57 \mathrm{aA}$ & $2.56 \mathrm{aA}$ \\
\hline & 3 & & $2.35 \mathrm{aB}$ & $2.50 \mathrm{aA}$ & $2.36 \mathrm{aB}$ & $2.47 \mathrm{aA}$ & $2.43 \mathrm{aA}$ \\
\hline \multirow{6}{*}{ ME } & 1 & \multirow{3}{*}{ Leaf } & $2.48 \mathrm{aA}$ & $2.47 \mathrm{aA}$ & $2.34 \mathrm{aA}$ & $2.43 \mathrm{aA}$ & $2.36 \mathrm{aA}$ \\
\hline & 2 & & $2.19 \mathrm{aB}$ & $2.34 \mathrm{aAB}$ & $2.29 \mathrm{aAB}$ & $2.31 \mathrm{aB}$ & $2.32 \mathrm{aAB}$ \\
\hline & 3 & & $2.19 \mathrm{aB}$ & $2.10 \mathrm{aB}$ & $2.14 \mathrm{aB}$ & $2.27 \mathrm{aB}$ & $2.29 \mathrm{aB}$ \\
\hline & 1 & \multirow{3}{*}{ Stem } & $2.34 \mathrm{aA}$ & $2.14 \mathrm{cdA}$ & $2.16 \mathrm{cA}$ & $2.25 \mathrm{bA}$ & $2.11 \mathrm{dA}$ \\
\hline & 2 & & $2.04 \mathrm{aAB}$ & $2.08 \mathrm{aA}$ & $2.09 \mathrm{aA}$ & $2.11 \mathrm{aA}$ & $2.10 \mathrm{aA}$ \\
\hline & 3 & & $1.92 \mathrm{aB}$ & $2.05 \mathrm{aA}$ & $1.94 \mathrm{aB}$ & $2.02 \mathrm{aA}$ & $1.99 \mathrm{aA}$ \\
\hline
\end{tabular}

$\mathrm{CP}$ - crude protein (\%); TDN - total digestible nutrient (\%); DE - digestible energy (Mcal/kg/DM); ME - metabolizable energy (Mcal/kg/MS). Means followed by different lowercase letters in the rows and uppercase letters in the columns differ by the Tukey test at $5 \%$ significance.

Table 8. Total dry mass production (TDMP) of Xaraes palisadegrass per kilogram of fertilizer $\left(\mathrm{kg} \mathrm{kg}^{-1}\right)$ and per unit of real $(\mathrm{kg} / \mathrm{R} \$ 1.00)$ invested per hectare.

\begin{tabular}{ccccccc}
\hline \multirow{2}{*}{\begin{tabular}{c} 
Variable \\
\cline { 3 - 6 }
\end{tabular}} & Cut & Urea & Super N & $08-28-16$ & $20-10-10$ & $30-00-20$ \\
\cline { 3 - 6 } & 1 & $13.71 \mathrm{aA}$ & $17.25 \mathrm{aA}$ & $14.85 \mathrm{aA}$ & $17.34 \mathrm{aA}$ & $19.92 \mathrm{aA}$ \\
TDMP $\left(\mathrm{kg} \mathrm{kg}^{-1}\right)$ & 2 & $18.06 \mathrm{aA}$ & $22.62 \mathrm{aA}$ & $22.08 \mathrm{aA}$ & $25.23 \mathrm{aA}$ & $24.48 \mathrm{aA}$ \\
& 3 & $18.99 \mathrm{aA}$ & $22.71 \mathrm{aA}$ & $24.87 \mathrm{aA}$ & $28.56 \mathrm{aA}$ & $26.97 \mathrm{aA}$ \\
\hline & 1 & $8.97 \mathrm{aA}$ & $10.14 \mathrm{aA}$ & $10.38 \mathrm{aA}$ & $11.55 \mathrm{aA}$ & $14.22 \mathrm{aA}$ \\
TDMP $(\mathrm{kg} / \mathrm{R} \$ 1.00)$ & 2 & $11.79 \mathrm{aA}$ & $13.29 \mathrm{aA}$ & $15.45 \mathrm{aA}$ & $16.80 \mathrm{aA}$ & $17.49 \mathrm{aA}$ \\
& 3 & $12.39 \mathrm{aA}$ & $13.35 \mathrm{aA}$ & $17.40 \mathrm{aA}$ & $19.02 \mathrm{aA}$ & $19.26 \mathrm{aA}$ \\
\hline
\end{tabular}

TDMP - total dry mass production $\left(\mathrm{kg} \mathrm{ha}^{-1}\right)$. Means followed by different lowercase letters in the rows and uppercase letters in the columns differ by the Tukey test at $5 \%$ significance. 


\section{Literature Cited}

AOAC, Association of Official Analytical Chemists 1990. Official methods of analysis. 15. ed. Association of Official Analytical Chemists. Washington. USA, $406 \mathrm{p}$.

Barcellos, A.O.; Ramos, A.K.B.; Vilela, L. and Martha Junior, G.B. 2008. Sustentabilidade da produção animal baseada em pastagens consorciadas e no emprego de leguminosas exclusivas, na forma de banco de proteína, nos trópicos brasileiros. Revista Brasileira de Zootecnia, 37: 51-67.

Benett, C.G.S.; Buzetti, S.; Silva, K.S.; Bergamaschine, A.F. and Fabrício, J.A.

2008. Produtividade e composição bromatológica do capim-marandu a fontes e doses de nitrogênio. Ciência e Agrotecnologia, 32 (5): 1629-1636.

Costa, K.A.P.; Oliveira, I.P.; Faquin, V.; Silva, G.P. and Severiano, E.C.

2009. Produção de massa seca e nutrição nitrogenada de cultivares de Brachiaria brizantha (A. Rich) Stapf sob doses de nitrogênio. Ciência e Agrotecnologia, 33 (6): 1578-1585.

Costa, K.A.P.; Severiano, E.C.; Silva, F.G.; Borges, E.F.; Epifânio, O.S. and Guimarães, K.C.

2013. Doses and sources of nitrogen on yield and bromatological composition of Xaraés grass. Ciência Animal Brasileira, 14 (3): 288-298.

Dupas, E.; Buzetti, S.; Rabêlo, F.H.S.; Sarto, A.L.; Cheng,

N.C.; Teixeira Filho, M.C.M.; Galindo, F.S.; Dinalli, R.P. and

Gazola, R.N.

2016a. Nitrogen recovery, use efficiency, dry matter yield, and chemical composition of palisade grass fertilized with nitrogen sources in the Cerrado biome. Australian Journal of Crop Science, 10 (9): 1330-1338.

Dupas, E.; Buzetti, S.; Rabêlo, F.H.S. and Sarto, A.L.

2016b. Carbon and carbon dioxide accumulation by marandu grass under nitrogen fertilization and irrigation. Revista Ceres, 63 (3): 387-393.

EMBRAPA, Empresa Brasileira de Pesquisa Agropecuária 2013. Sistema brasileiro de classificação de solos. 3. ed. Embrapa Solos. Rio de Janeiro. Brazil, 353 p.

Fagundes, J.L.; Fonseca, D.M.; Morais, R.V.; Mistura, C.; Vitor, C.M.T.; Gomide, J.A.; Nascimento Junior, D.; Santos, M.E.R. and Lambertucci, D.M.

2006. Avaliação das características estruturais do capimbraquiária em pastagens adubadas com nitrogênio nas quatro estações do ano. Revista Brasileira de Zootecnia, 35 (1): 30-37.

Fagundes, J.L.; Fonseca, D.M.; Mistura, C.; Salgado, L.T.; Queiroz, D.S.; Morais, R.V.; Vitor, C.M.T. and Moreira, L.M. 2007. Adubação nitrogenada e potássica em capim-elefante cv. Napier sob pastejo rotativo. Boletim de Indústria Animal, 64 (2): $149-158$

Gatiboni, L.C.; Kaminski, J.; Pellegrini, J.B.R. and Aquino, J.E.R. 2008. Efeito da adubação fosfatada e da calagem sobre a qualidade bromatológica da forragem de pastagem natural com introdução de espécies forrageiras de inverno. Revista Brasileira de Agrociência, 14 (3-4): 125-134.

Goering, H.K. and Van Soest, P.J.

1970. Forage fiber analysis (Apparatus, reagents, procedures and some applications). United States Department of Agriculture. Washington. USA, $20 \mathrm{p}$.
Lopes, J.; Evangelista, A.R.; Cardoso, P.J.; Queiroz, D.S. and Muniz, J.A.

2011. Doses de fósforo no estabelecimento de capim-xaraés e estilosantes Mineirão em consórcio. Revista Brasileira de Zootecnia, 40 (12): 2658-2665.

Martuscello, J.A.; Fonseca, D.M.; Nascimento Júnior, D.; Santos, P.M.; Cunha, D.N.F.V. and Moreira, L.M.

2006. Características morfogênicas e estruturais de capimmassai submetido a adubação nitrogenada e desfolhação. Revista Brasileira de Zootecnia, 35 (3): 665-671.

Oliveira, A.B.; Pires, A.J.V.; Matos Neto, U.; Carvalho, G.G.P.; Veloso, C.M. and Silva, F.F.

2007. Morfogênese do capim-tanzânia submetido a adubações e intensidades de corte. Revista Brasileira de Zootecnia, 36 (4): 1006-1013.

Rabêlo, F.H.S.; Rezende, A.V.; Rabelo, C.H.S. and Amorim, F.A. 2013. Características agronômicas e bromatológicas do milho submetido a adubações com potássio na produção de silagem. Revista Ciência Agronômica, 44 (3): 635-643.

Rezende, A.V.; Lima, J.F.; Rabelo, C.H.S.; Rabêlo, F.H.S.; Nogueira, D.A.; Carvalho, M.; Faria Junior, D.C.N.A. and Barbosa, L.A.

2011. Características morfofisiológicas da Brachiaria brizantha $\mathrm{cv}$. Marandu em resposta à adubação fosfatada. Agrarian, 4 (14): 335-343.

Rezende, A.V.; Rabêlo, F.H.S.; Rabelo, C.H.S.; Lima, P.P.; Barbosa, L.A.; Abud, M.C. and Souza, F.R.C. 2015. Características estruturais, produtivas e bromatológicas dos capins Tifton 85 e Jiggs fertilizados com alguns macronutrientes. Semina: Ciências Agrárias, 36 (3): 1507-1518.

Rodrigues, R.C.

2009. Avaliação químico-bromatológica de alimentos produzidos em terras baixas para nutrição animal. Empresa Brasileira de Pesquisa Agropecuária. Pelotas. Brazil, 31 p.

Rodrigues, M.; Rabêlo, F.H.S.; Bernardi, D.B. and Lange, A. 2015. Análise econômica de consórcios de Brachiaria brizantha com culturas graníferas anuais voltados para a recuperação de pastagens na Amazônia. Agrária, 10 (1): 82-90.

Santos, M.E.R.; Fonseca, D.M.; Pimentel, R.M.; Silva, G.P.; Gomes, V.M. and Silva, S.P.

2011. Número e peso de perfilhos no pasto de capim-braquiária sob lotação contínua. Acta Scientiarum. Animal Sciences, 33 (2): 131-136.

Silva, F.C.

1999. Manual de análises químicas de solos, plantas e fertilizantes. Embrapa. Brasília. Brazil, 370 p.

Sousa, R.S.; Pires, A.J.V.; Carvalho, G.G.P.; Silva, F.F.; Magalhães, A.F. and Veloso, C.M.

2010. Composição química de capim-tanzânia adubado com nitrogênio e fósforo. Revista Brasileira de Zootecnia, 39 (6): 1200-1205.

Telles, T.G.R.M.; Carneiro, M.S.S.; Soares, I.; Pereira, E.S.; Souza, P.Z. and Magalhães, J.A.

2011. Produção e composição química da Brachiaria brizantha cv. MG-4 sob efeito de adubação com NPK. Acta Scientiarum. Animal Sciences, 33 (2): 137-143.

Van Soest, P.J. 1994. Nutritional ecology of the ruminant. Cornell University. Ithaca. USA, $476 \mathrm{p}$. 